\title{
S-phase reduction in T47D human breast cancer epithelial cells induced by an S100P antisense-retroviral construct
}

\author{
BETTINA BEISSEL ${ }^{5}$, ISMAEL D.C.G. SILVA ${ }^{1}$, JOÃO B. PESQUERO ${ }^{3}$, JOSE RUSSO ${ }^{4}$, \\ NESTOR SCHOR ${ }^{2}$ and MARIA HELENA BELLINI ${ }^{2,5}$ \\ ${ }^{1}$ Gynecology Department, ${ }^{2}$ Nephrology Discipline, ${ }^{3}$ Biophysics Department, Federal University of São Paulo, SP, Brazil; \\ ${ }^{4}$ Breast Cancer Research Laboratory, Fox Chase Cancer Center, Philadelphia, PA, USA; \\ ${ }^{5}$ Centro de Química e Meio Ambiente, IPEN/CNEN-SP, São Paulo, SP, Brazil
}

Received August 29, 2006; Accepted November 13, 2006

\begin{abstract}
S100P is expressed in several malignant neoplasms. It was previously demonstrated that S100P is involved in the very early stages of breast carcinogenesis. In the present study we used a retrovirus-mediated transfer of antisense$\mathrm{S} 100 \mathrm{P}$ in order to check whether the decrease in expression of this protein could lead to alterations in the cell cycle of epithelial cells of human breast cancer. The T47D breast carcinoma cell line, a human breast epithelial cell that expresses high levels of S100P, was a tool used in this study to investigate the alteration in cell cycle induced by a retrovirus-mediated transfer of antisense-S100P. First we used the real-time PCR technique to quantify the gene expression. The results showed a reduction of $63 \%$ of expression within the T47D-S100P-A/S infected population compared with control T47D-LXSN clones. To determine the impact of the S100P antisense technique on protein expression in T47D cells, we performed immunofluorescence staining and analyzed the resulting images using a confocal microscope. The images showed much less pronounced antibody marking of the S100P protein in the T47D-S100PA/S compared with control cells. To evaluate whether the antisense approach caused any alteration in the cell cycle, we concluded the study with flow cytometric analysis of the cell distribution. Our findings indicated that, in our model, S100P-antisense cells showed a $23 \%$ reduction of cells at the S-phase. Using transduction techniques with an S100P antisense-retroviral construct we were able to demonstrate a significant reduction in S-phase of the T47D cell cycle. To the best of our knowledge, this is the first time that an
\end{abstract}

Correspondence to: Dr Ismael Dale Cotrim Guerreiro da Silva, Molecular Gynecology Laboratory, Gynecology Department, Federal University of São Paulo, Rua Pedro de Toledo 781, 4th Floor, 04039-032 São Paulo, SP, Brazil

E-mail: ismael.toco@epm.br

Key words: S100P, calcium-binding protein, antisense, T47D antisense approach has been used against S100P mRNA in breast cancer epithelial cells. The results showed here seem to further classify S100P as a protein that might be involved in the cell cycle imbalance observed during breast carcinogenesis.

\section{Introduction}

Calcium ions serve as secondary messengers during the control of biochemical pathways. This control of cellular transduction is partly achieved through interactions with $\mathrm{Ca}-$ binding proteins. The $\mathrm{S} 100$ family consists of $\mathrm{Ca}^{2+}$-binding proteins of the EF-hand type with at least 20 members $(1,2)$.

The functions of these proteins vary widely between individual members. One of the last members of the S100 family is S100P, a 95-amino acid protein first purified from the placenta and with restricted cell distribution in other tissues $(3,4)$. In esophageal epithelial cells S100P expression has been noted during differentiation indicating that it may play a role in normal development (5).

Although the specific function of S100P is unknown, it has been shown to play a role in the carcinogenic process. Indeed, S100P expression has been observed in various cancer cell lines including breast cancer, where it is associated with cellular immortalization, and prostate cancer $(6,7)$. In the CWR22-R prostate cancer xenograft model, S100P expression was decreased following androgen ablation, and subsequently reexpressed upon treatment with androgens (8).

In lung adenocarcinoma, in a gene-expression risk profile based on the genes most associated with patient survival, S100P was correlated with decreased survival (9). Diederichs and co-workers (10) provided evidence that expression of $\mathrm{S} 100 \mathrm{P}$ is associated with metastasis and predicts survival in early-stage non-small cell lung cancer. In addition, S100P was also found to be hypomethylated in pancreatic cancer cell lines and primary pancreatic carcinomas (11).

It was previously demonstrated that $\mathrm{S} 100 \mathrm{P}$ is involved in the very early stages of breast carcinogenesis $(6,12)$. In the present study we used a retrovirus-mediated transfer of antisense-S100P, in order to check whether the decrease in expression of this protein could lead to alterations in the cell cycle of epithelial cells of human breast cancer. 


\section{Materials and methods}

Cells and cell culture. The viral packaging cell lines GP+E-86 and $\mathrm{GP}+e n v \mathrm{Am} 12$ were used for the generation of recombinant retrovirus. Both cell lines were kindly provided by Dr A. Bank, Columbia University (Genetix Pharmaceuticals, Inc., Tarrytown, NY, USA). The T47D breast cancer cell line was a gift from Dr Maria Mitzie Brentani, São Paulo State University, Brazil. All cells were cultured in DMEM (GibcoBRL), supplemented with $10 \%$ FBS (Gibco-BRL), $100 \mathrm{U} / \mathrm{ml}$ penicillin, $100 \mu \mathrm{g} / \mathrm{ml}$ streptomycin (Gibco-BRL) and glutamine $(4 \mathrm{mM})$, maintained at $37^{\circ} \mathrm{C}$ in a humidified $5 \%$ $\mathrm{CO}_{2}$ atmosphere and cultured at subconfluency by passaging with trypsin/EDTA (Gibco- BRL).

Construction of retroviral vector. The S100P-expressing replication-deficient retrovirus vector was constructed as follows: S100P cDNA was released from pET 3a vector by the PCR technique using Platinum Pfx DNA polymerase (Invitrogen) and primers with XhoI (5') and EcoRI (3')

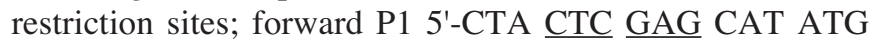
ACG GAA CTA G-3' and reverse P2 5'-TTA GAA TTC GGA TCC AGG GCA TCA T. cDNA and pLXSN vector were digested with EcoRI and XhoI enzymes (Promega) and the products were used in the ligation reaction sites of the pLXSN enzymes. After confirmation of insert antisense orientation with SacI (Promega) digestion, this construction was called LS100PSN-AS.

Production of replication-defective retrovirus. GP $+\mathrm{E}-86$ ecotropic retroviral packaging cells were transfected with retroviral vector (LS100PSN-AS or LXSN) separately, by the $\mathrm{CaCl}_{2}$ precipitation method. Subsequently, GP+E-86 medium was used to infect the amphotropic GP+envAm12 packaging cell line, and individual G418-resistant clones were selected as described (13). For each isolated clone, the viral titer was determined by fibroblast infection (13) and the clones of packaging cell lines with highest viral titers were used to infect T47D cells.

Transduction of T47D cells. By using the supernatants of the above packaging cells, T47D cells $\left(4 \times 10^{5}\right)$ were infected in $100-\mathrm{mm}$ plates. After $48 \mathrm{~h}$ the media was changed and supplemented with $0.5 \mathrm{mg} / \mathrm{ml} \mathrm{G} 418$ and selected for resistance at 2 weeks when individual clones were isolated $(14,15)$. Clones containing the antisense were named S100PA/S.

RNA extraction. Total RNA was extracted using TRIZOL ${ }^{\circledR}$ reagent (Invitrogen), followed by RNA extraction with $200 \mu \mathrm{l}$ chloroform and precipitation with $500 \mu 1$ isoprophanol. The pellets were washed in $75 \%$ ethanol and re-suspended in $50 \mu 1$ RNase-free water. RNA content and quality were assessed by agarose/formaldehyde gel eletrophoresis and spectrophotometry at $260 \mathrm{~nm}(16)$.

Reverse transcription. Prior to the transcription, RNA was treated with DNase I (Invitrogen) at $25^{\circ} \mathrm{C}$ for $15 \mathrm{~min}$. The isolated RNA was reverse transcribed into cDNA with $2 \mu \mathrm{l}$ oligo-dT primer (Invitrogen), at $65^{\circ} \mathrm{C}$ for $10 \mathrm{~min}, 1 \mu \mathrm{BSA}$ (Promega), $10 \mu 1$ 5X First-strand buffer, $10 \mu 1$ deoxy- nucleotide triphosphate (dNTP) $10 \mathrm{mM}, 2.5 \mu \mathrm{l} \mathrm{MgCl}_{2}$ and $2 \mu \mathrm{l}$ M-MLV reverse transcriptase, and incubated for $1 \mathrm{~h}$ at $37^{\circ} \mathrm{C}$ $(17,18)$.

Real-time PCR. cDNA was amplified by using SYBR ${ }^{\circledR}$ Green PCR master mix (Applied Biosystems). The real-time PCRs were performed in an ABI PRISM model 7700 sequence detector (Perkin-Elmer Applied Biosystems) under the following conditions: $95^{\circ} \mathrm{C}$ for $10 \mathrm{~min}$, followed by 40 cycles at $94^{\circ} \mathrm{C}$ for $15 \mathrm{sec}, 55^{\circ} \mathrm{C}$ for $30 \mathrm{sec}$, and $72^{\circ} \mathrm{C}$ for $30 \mathrm{sec}$. The optimal concentration of primers was determined in preliminary experiments. The sequences of primers are as follows: forward 5'-AAT TGC TCA AGG ACC TGG ACG3' and reverse: 5'-GCA TCA TTT GAG TCC TGC CTT C-3'. Cyclophilin A was used as a reference housekeeping gene with the following primers: forward 5'-CAA ATG CTG GAC CCA ACA CA-3' and reverse 5'-TTG CCA AAC ACC ACA TGC TT-3'. Real-time PCR was performed in triplicate (19).

Flow cytometric analysis. For the flow cytometric analysis, $1 \times 10^{6}$ cells from each clone were harvested in trypsin, washed with cold PBS, fixed in $1 \mathrm{ml}$ cold $70 \%$ ethanol, and stored at $4{ }^{\circ} \mathrm{C}$. At the day of analysis, cells were washed twice with cold PBS, treated with $100 \mu \mathrm{g} / \mathrm{ml}$ RNase A, and stained with $50 \mu \mathrm{g} / \mathrm{ml}$ propidium iodide (Sigma). Analysis of DNA content was performed in a Becton Dickinson FACSCalibur flow cytometer (BD Biosciences) with 10.000 events. Results were analyzed with ModFit software (version 2.0, Verity Software, Inc., Topsham, ME, USA). The experiment was repeated three times in duplicate $(20,21)$.

Confocal microscopy. To determine the impact of S100P antisense on protein expression in T47D cells, immunofluorescence staining was performed. Cells were seeded at a density of $5 \times 10^{4}$ cells on chamber glass slides (Nalge, NUNC) and cultured overnight. Cells were washed twice with PBS, fixed with $4 \%$ cold paraformaldehyde at $4^{\circ} \mathrm{C}$ for 10 min after blocking with bovine serum albumin and $0.1 \mathrm{M}$ glicine, and then permeabilized with $0.01 \%$ saponin for $10 \mathrm{~min}$ and subsequently incubated with monoclonal anti-S100P antibody (BD Transduction Laboratories) overnight at $4{ }^{\circ} \mathrm{C}$ in the dark. The cells were then incubated with polyvalent FITC-conjugated immunoglobulin (Sigma) and DAPI (4,6diamidino-2-phenylindole) for $30 \mathrm{~min}$ at room temperature. After several washes with PBS, coverslips were mounted and the immunofluorescence images were obtained in a Zeiss inverted fluorescence microscope Axiovert $100 \mathrm{M}$. For data collection and image analysis LSM 510 software was utilized (22).

Statistical analysis. The data are presented as mean \pm SD for the number of experiments. Statistical significance was $\mathrm{P}<0.05$.

\section{Results}

Real-time PCR. Real-time PCR quantification was based on threshold PCR cycle number $\left(\mathrm{C}_{\mathrm{T}}\right)$ values, when the increase in fluorescent signal of the PCR product showed exponential amplification. The target gene mRNA was normalized to the housekeeping gene cyclophilin A. This gene is stable in 


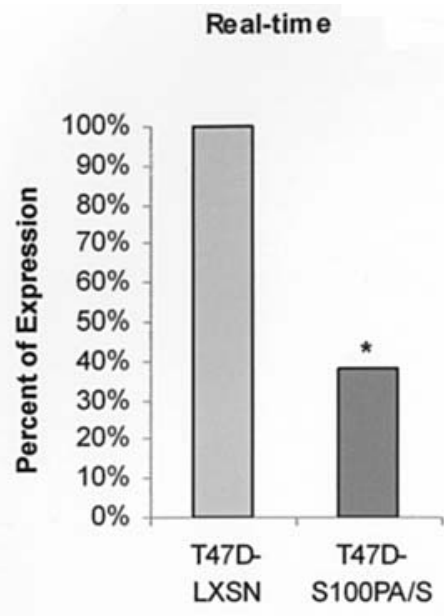

Figure 1. Percent expression of S100P gene in T47D mammary tumor cell line. Data are expressed as percentage of expression. The expression of control is considered $100 \%$ and the expression of T47D-S100P/As represents $37 \%$ of the control expression. Each point represents the mean \pm standard error of triplicate measurements from 2 independent experiments. ${ }^{*}$ Significantly different, control vs. T47D-S100P/Antisense; Student's t-test, $\mathrm{P}<0.001$.

many physiological and pathophysiological conditions (19). The relative expression level of the target gene compared to that of the housekeeping gene was calculated as $2^{-\Delta C T}$, where $\Delta \mathrm{Ct}=\mathrm{Ct} \mathrm{S} 100 \mathrm{P}$ gene $-\mathrm{Ct}$ cyclophilin gene. The ratio of relative expression of the T47D-S100P/AS gene to that of T47D-LXSN was then calculated as $2^{-\Delta \Delta C T}$, where $\Delta \Delta \mathrm{Ct}=$ $\Delta \mathrm{Ct}_{\mathrm{T} 47 \mathrm{D}-\mathrm{S} 100 \mathrm{P} / \mathrm{AS}}-\Delta \mathrm{Ct}_{\mathrm{T} 47 \mathrm{D}-\mathrm{LXSN}}(23)$. Fig. 1 shows the results of T47D-S100P/AS and cyclophilin A assay in two independent experiments in triplicate $(n=6)$. All triplicate amplification resulted in very similar $\mathrm{C}_{\mathrm{T}}$ values; the standard deviation did not exceed 0.35 for any sample. The results showed a reduction of $63 \%$ in the expression of T47D-S100PA/S.

Cell cycle analysis. We cultured the T47D-LXSN and T47DLS100PA/S clones under the same conditions, and observed a decrease in cellular proliferation in the antisense clones compared to the control without any significant cell death. We decided to analyze the cell cycle by flow cytometry, and this growth inhibition was in agreement with an increase in the percentage of cells in the $\mathrm{G}_{0} / \mathrm{G}_{1}$-phase of the cell cycle and with a decrease of the S-phase fraction (Table I) of T47D-S100P/AS cells. The proportion of cells in the S-phase decreased significantly $(\mathrm{P}<0.01$ compared with control);

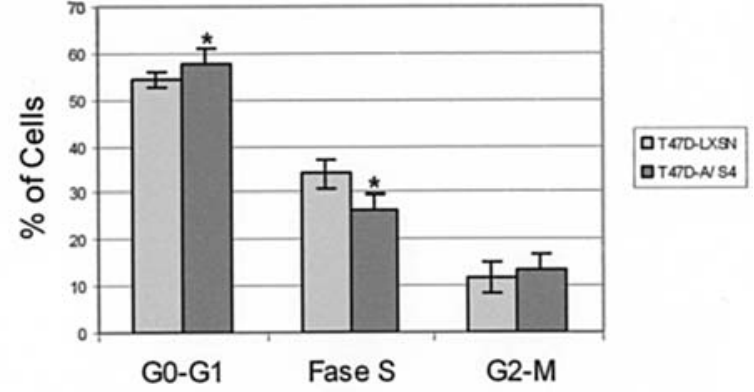

Figure 2. Cell distribution according to the phase of the cell cycle. The fluorescence of individual cells was measured by flow cytometry. Cell debris and aggregates were excluded as described in Materials and methods. Each bar represents the mean \pm standard error of at least 3 separate experiments. Statistical significance was determined using the Student's t-test; ${ }^{*} \mathrm{P}<0.01$, significantly different, control vs. T47D-S100P/Antisense.

once the S-phase fraction (SPF) is considered a prognostic factor in breast cancer, this result seems to be noteworthy.

The data obtained with flow cytometry were stored and the ModFit program was used for analysis of cell cycle distribution. As shown in Fig. 2, 34.04\% control cells were at the S-phase whereas $26.40 \%$ from the transducted cells were at the same phase. These findings indicated that, in our model, S100P-antisense cells showed a $23 \%$ reduction of cells at the S-phase.

Confocal microscopy. The next step was to prove if, after the reduction of transcription, efficiency of the S100P-A/S gene also reflects a decrease in protein expression. Four T47DS100P/AS clones were grown on chamber slides, formalinfixed and examined by immunofluorescent microscopy for detection of S100P (shown in green). The nuclei were stained with DAPI (shown in blue) (Fig. 3). We examined the cellular distribution of S100P in the T47D-S100P/AS and T47DLXSN clones using antiS100P antibody and, to note, S100P remained less intensive in the transfected T47D cells.

\section{Discussion}

In the present study, by using a functional retroviral delivery system, we were able to demonstrate that the S100P calciumbinding protein seems to be an important element favoring cell division in human breast cancer cells.

Indeed, our antisense strategy against S100P was able to significantly reduce, not only cellular protein levels, but

Table I. Effect of antisense transduction on cell cycle distribution of T47D cells.

\begin{tabular}{|c|c|c|c|c|c|}
\hline \multicolumn{2}{|c|}{$\mathrm{G}_{0} / \mathrm{G}_{1}$-phase $(\%)$} & \multicolumn{2}{|c|}{ S-phase $(\%)^{\mathrm{a}}$} & \multicolumn{2}{|c|}{$\mathrm{G}_{2} / \mathrm{M}$-phase $(\%)$} \\
\hline T47D-mock & T47D-antisense & T47D-mock & T47D-antisense & T47D-mock & T47D-antisense \\
\hline $54.07 \pm 2.17$ & $57.73 \pm 1.25$ & $34.04 \pm 3.17$ & $26.40 \pm 3.35$ & $11.89 \pm 3.47$ & $13.26 \pm 3.67$ \\
\hline
\end{tabular}

Each point represents the mean \pm standard error of at least 3 separate experiments. Statistical significance was determined using the Student's t-test; ${ }^{\mathrm{a}} \mathrm{P}<0.01$, significantly different, control vs. T47D-S100P/AS. 


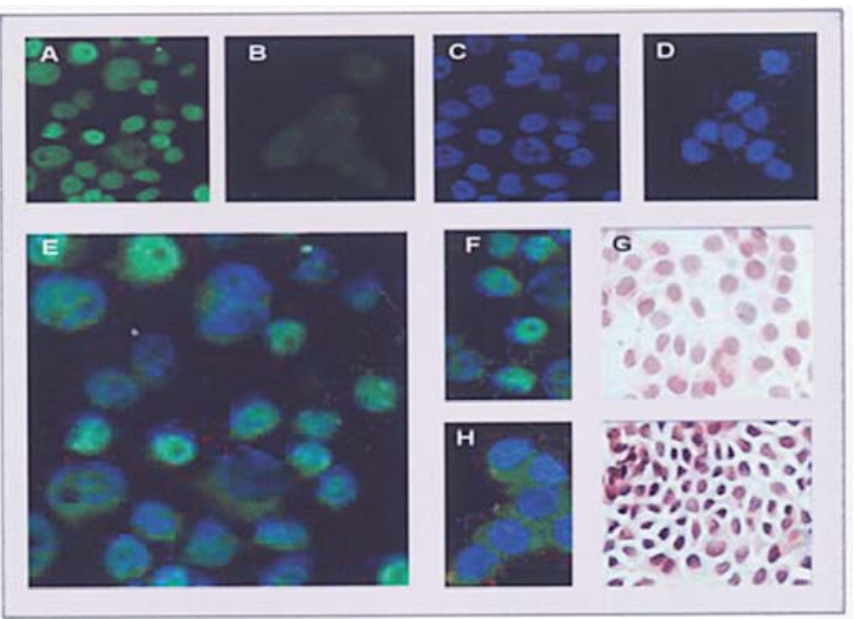

Figure 3. Immunofluorescent microscopy for S100P detection in T47DLXSN cells (A,C,E,F) and T47D-S100P/Antisense (B,D,H). Nuclear DAPI staining for T47D-LXSN and T47D-S100P/Antisense, respectively (C,D). Superimposed double staining $(\mathrm{E}, \mathrm{F}, \mathrm{H})$. Confocal microscopy shows different staining intensity patterns: T47D-LXSN/AS (A) shows intense immunofluorescent detection of S100P when compared to the antisense cells T47D-S100P/AS (B). Changes in nuclear morphology (H\&E staining, $x 400$ ) can also be seen when comparing T47D cells before $(\mathrm{G})$ and after antisense therapy for S100P (I)

more importantly, the number of cancer cells in S-phase when compared to controls.

These findings are in agreement with our previous results showing that the overexpression of this protein is associated with immortalization of human breast epithelial cells in vitro and early stages of breast cancer development in vivo (6).

$\mathrm{S} 100 \mathrm{P}$ was first purified from the placenta (4), and is associated with a large number of diseases. It has been detected in esophageal epithelial cells during differentiation (5), with doxorubicin resistance in colon cancer cells (24), and with androgen independence in prostate cancer (8). S100P levels are also significantly associated with the disease progression of prostate and pancreatic carcinomas $(11,25-27)$ and with the aggressiveness of pancreatic cancer (28). It has been described to be upregulated in intraductal papillary mucinous neoplasms (29), and a decreased survival of patients with lung cancer has also been shown to correlate with S100P overexpression (9).

Although the biological effects of S100P remain to be fully elucidated, Arumugam and colleagues (30) have demonstrated an interaction between S100P and the receptor for activated glycation end products (RAGE) that acts in an autocrine manner to stimulate cell proliferation and survival. Our results are in complete agreement with these findings.

Regarding our choice of T47D cells as a model, it is important to mention that this breast cancer cell line was found to overexpress S100P in our previous study (6). However, in order to analyze the overexpression in human breast tissues in a larger sample of patients, we recently assessed, by immunohistochemistry, a total of 155 samples from patients submitted to stereotactic vacuum-assisted core biopsy due to breast microcalcifications (12). Results showed a positive association between estrogen receptor (ER) and S100P overexpression as well as a clear positive association between S100P overexpression and the risk of breast cancer.
The strong association of S100P and ER expression highlights our hypothesis about the possible role played by S100P in the very early stages of breast carcinogenesis (12).

It seems that $\mathrm{S} 100 \mathrm{P}$ is able to transport calcium out of the cell with two consequences: the reduction of intracytoplasmatic calcium concentration and calcium precipitation in the extracellular environment. Since increments in intracellular calcium concentration are responsible for mechanisms which can lead to senescence and programmed cell death in breast epithelial cells $(31,32)$, apoptosis would be blocked by S100P.

Regarding the ability of S100P to elicit proliferation, we found an important positive correlation between the proliferation marker MIB and S100P expression in our preinvasive breast carcinoma clinical samples (12). Still, regarding breast carcinoma, Wang et al (33) recently demonstrated that survival of patients with S100P-positive carcinomas is significantly reduced $\sim 7$-fold than for those with negatively stained carcinomas.

Concerning the mechanism through which this protein is upregulated, it seems that the methylation status of S100P may answer this question. Indeed, S100P was found to be aberrantly hypomethylated in a large fraction of pancreatic cancer cell lines and primary pancreatic carcinomas (11).

In conclusion, to the best of our knowledge, this is the first time that an antisense approach was used against S100P mRNA in breast cancer epithelial cells. The results demonstrated here further classify S100P as a protein that may be involved in the cell cycle imbalance observed during breast carcinogenesis.

\section{Acknowledgements}

This study was supported by Conselho Nacional de Desenvolvimento Científico e Tecnológico CNPq - Brasil, nr. 134085, Instituto de Pesquisas Energéticas e Nucleares IPEN and Universidade Federal de São Paulo - Escola Paulista de Medicina (UNIFESP-EPM).

\section{References}

1. Gribenko A, Lopez MM, Richardson JM III and Makhatadze GI: Cloning, overexpression, purification, and spectroscopic characterization of human S100P. Protein Sci 7: 211-215, 1998.

2. Donato R: S100: a multigenic family of calcium-modulated proteins of the EF-hand type with intracellular and extracellular functional roles. Int J Biochem Cell Biol 33: 637-668, 2001.

3. Emoto Y, Kobayashi R, Akatsuda H and Hidaka H: Purification and characterization of a new member of the S-100 protein family from human placenta. Biochem Biophys Res Commun 182: 1246-1253, 1992.

4. Becker T, Gerke V, Kube E and Weber K: S100P, a novel $\mathrm{Ca}(2+)$-binding protein from human placenta: cDNA cloning, recombinant protein expression and $\mathrm{Ca} 2+$ binding properties. Eur J Biochem 207: 541-547, 1992.

5. Sato N and Hitomi J: S100P expression in human esophageal epithelial cells: human esophageal epithelial cells sequentially produce different S100 proteins in the process of differentiation. Anat Rec 267: 60-69, 2002.

6. Guerreiro Da Silva ID, Hu YF, Russo IH, Ao X, Salicioni AM, Yang $X$ and Russo J: S100P calcium-binding protein overexpression is associated with immortalization of human breast epithelial cells in vitro and early stages of breast cancer development in vivo. Int J Oncol 16: 231-240, 2000.

7. Averboukh L, Liang P, Kantoff PW and Pardee AB: Regulation of S100P expression by androgen. Prostate 29: 350-355, 1996. 
8. Amler LC, Agus DB, LeDuc C, Sapinoso ML, Fox WD, Kern S, Lee D, Wang V, Leysens M, Higgins B, Martin J, Gerald W, Dracopoli N, Cordon-Cardo C, Scher HI and Hampton GM: Dysregulated expression of androgen-responsive and nonresponsive genes in the androgen-independent prostate cancer xenograft model CWR22-R1. Cancer Res 60: 6134-6141, 2000.

9. Beer DG, Kardia SL, Huang CC, Giordano TJ, Levin AM, Misek DE, Lin L, Chen G, Gharib TG, Thomas DG, Lizyness ML, Kuick R, Hayasaka S, Taylor JM, Iannettoni MD, Orringer MB and Hanash S: Gene-expression profiles predict survival of patients with lung adenocarcinoma. Nat Med 8: 816-824, 2002.

10. Diederichs S, Bulk E, Steffen B, Ji P, Tickenbrock L, Lang K, Zänker KS, Metzger R, Schneider PM, Gerke V, Thomes M, Berdel WE, Serve HE and Müller-Tidow C: S100 family members and trypsinogens are predictors of distant metastasis and survival in early-stage non-small cell lung cancer. Cancer Res 64: 5564-5569, 2004.

11. Sato N, Fukushima N, Matsubayashi H and Goggins M: Identification of maspin and S100P as novel hypomethylation targets in pancreatic cancer using global gene expression profiling. Oncogene 26;23: 1531-1538, 2004.

12. Schor APT, Carvalho FM, Kemp C, Guerreiro da Silva IDC and Russo J: S100P calcium-binding protein expression is associated with high risk proliferative lesions of the breast. Oncol Rep 15: 3-6, 2006.

13. Bellini MH, Peroni CN and Bartolini PO: Increases in weight of growth hormone-deficient and immunodeficient (lit/scid) dwarf mice after grafting of hGH secreting, primary human keratinocytes. FASEB J 17: 2322-2324, 2003.

14. Sartorius CA, Shen T and Horwitz KB: Progesterone receptors $\mathrm{A}$ and $\mathrm{B}$ differentially affect the growth of estrogen-dependent human breast tumor xenografts. Breast Cancer Res Treat 79: 287-299, 2003.

15. Chisamore MJ, Ahmed Y, Bentrem DJ, Craig Jordan V and Tonetti DA: Novel antitumor effect of estradiol in athymic mice injected with a T47D breast cancer cell line overexpressing protein kinase C $\alpha$. Clin Cancer Res 7: 3156-3165, 2001.

16. Chomczynski P and Sacchi N: Single-step method of RNA isolation by acid guanidinium thiocyanate-phenol-chloroform extraction. Anal Biochem 162: 156-159, 1987.

17. D'alessio JM and Gerard GF: Second-strand cDNA synthesis with $E$. coli DNA polymerase I and RNase $\mathrm{H}$ : the fate of information at the mRNA 5 'terminus and the effect of $E$. coli DNA ligase. Nucleic Acids Res 16: 1999-2014, 1988.

18. Kotewicz ML, Sampson CM, D'Alessio JM and Gerard GF: Isolation of cloned Moloney murine leukaemia virus reverse transcription lacking ribonuclease $\mathrm{H}$ activity. Nucleic Acids Res 16: 265-277, 1988.

19. Peinnequin A, Mouret C, Birot O, Alonso A, Mathieu J, Clarençon D, Agay D, Chancerelle Y and Multon E: Rat proinflammatory cytokine and cytokine related mRNA quantification by real-time polymerase chain reaction using SYBR green. BMC Immunol 5: 3, 2004.

20. Vindelov LL and Christensen IJ: A review of techniques and results obtained in one laboratory by an integrated system of methods designed for routine clinical flow cytometric DNA analysis. Cytometry 11: 753-770, 1990.
21. Michea I, Fergusson DR, Peters EM, Andrews PM, Kirby MR and Burg MB: Cell cycle delay and apoptosis are induced by high salt and urea in renal medullary cells. Am J Physiol Renal Physiol 278: F209-F218, 2000.

22. Yang ES and Burnstein KL: Vitamin D inhibits $G_{1}$ to $S$ progression in $\mathrm{LNCaP}$ prostate cancer cells through $\mathrm{p} 27^{\mathrm{Kip} 1}$ stabilization and Cdk2 mislocalization to the cytoplasm. J Biol Chem 278: 46862-46868, 2003.

23. Yang J, Wong RK, Wang X, Moibi J, Hessner MJ, Greene S, Wu J, Sukumvanich S, Woolf BA and Gao Z: Leucine culture reveals that ATP synthase functions as a fuel sensor in pancreatic B cells. J Biol Chem 279: 53915-53923, 2004.

24. Bertram J, Palfner K, Hiddemann W and Kneba M: Elevated expression of S100P, CAPL and MAGE 3 in doxorubicinresistant cell lines: comparison of mRNA differential display reverse transcription-polymerase chain reaction and subtractive suppressive hybridization for the analysis of differential gene expression. Anticancer Drugs 9: 311-317, 1998.

25. Crnogorac-Jurcevic T, Missiaglia E, Blaveri E, Gangeswaran R, Jones M, Terris B, Costello E, Neoptolemos JP and Lemoine NR: Molecular alterations in pancreatic carcinoma: expression profiling shows that dysregulated expression of S100 genes is highly prevalent. J Pathol 201: 63-74, 2003.

26. Mousses S, Bubendorf L, Wagner U, Hostetter G, Kononen J, Cornelison R, Goldberger N, Elkahloun AG, Willi N, Koivisto P, Ferhle W, Raffeld M, Sauter G and Kallioniemi OP: Clinical validation of candidate genes associated with prostate cancer progression in the CWR22 model system using tissue microarrays. Cancer Res 62: 1256-1260, 2002.

27. Iacobuzio-Donahue CA, Maitra A, Shen-Ong GL, van Heek T, Ashfaq R, Meyer R, Walter K, Berg K, Hollingsworth MA, Cameron JL, Yeo CJ, Kern SE, Goggins $M$ and Hruban RH: Discovery of novel tumor markers of pancreatic cancer using global gene expression technology. Am J Pathol 160: 1239-1249, 2002.

28. Arumugam T, Simeone DM, van Golen K and Logsdon CD: S100P promotes pancreatic cancer growth, survival and invasion. Clin Cancer Res 11: 5356-5364, 2005.

29. Terris B, Blaveri E, Crnogorac-Jurcevic T, Jones M, Missiaglia E, Ruszniewski P, Sauvanet A and Lemoine NR: Characterization of gene expression profiles in intraductal papillary-mucinous tumors of the pancreas. Am J Pathol 160: 1745-1754, 2002.

30. Arumugam T, Simeone DM, Schmidt AM and Logsdon CD: S100P stimulates cell proliferation and survival via RAGE. J Biol Chem 279: 5059-5065, 2003.

31. Koltzscher M, Neumann C, Konig S and Gerke V: Ca2+dependent binding and activation of dormant ezrin by dimeric S100P. Mol Biol Cell 14: 2372-2384, 2003.

32. Filipek A, Jastrzebska B, Nowotny $M$ and Kuznicki J: CacyBP/SIP, a calcyclin and Siah-1-interacting protein, binds EF-hand proteins of the S100 family. J Biol Chem 277: 28848-28852, 2002.

33. Wang G, Platt-Higgins A, Carroll J, de Silva Rudland S, Winstanley J, Barraclough R and Rudland PS: Induction of metastasis by $\mathrm{S} 100 \mathrm{P}$ in a rat mammary model and its association with poor survival of breast cancer patients. Cancer Res 66: 1199-1207, 2006. 